\title{
Tumor necrosis factor-alpha G-238A polymorphism and coronary artery disease risk: a meta-analysis of 4,222 patients and 4,832 controls
}

This article was published in the following Dove Press journal:

Therapeutics and Clinical Risk Management

23 September 2015

Number of times this article has been viewed

\author{
Xian-Ping Hua ${ }^{1, *}$ \\ Xiao-Dong Zhang,** \\ Joey SW Kwong ${ }^{3, *}$ \\ Xian-Tao Zeng ${ }^{4}$ \\ Zhen-Jian Zhang' \\ Wan-Lin Wei ${ }^{2}$ \\ 'Department of Cardiology, Suizhou \\ Hospital, Hubei University of \\ Medicine, Suizhou, Hubei Province, \\ ${ }^{2}$ Department of Cardiology and 4th \\ Cadres Ward, General Hospital of \\ Beijing Military Command, Beijing, \\ ${ }^{3}$ Chinese Evidence-Based Medicine \\ Center and Chinese Cochrane \\ Center, West China Hospital, Sichuan \\ University, Chengdu, ${ }^{4}$ Center for \\ Evidence-Based and Translational \\ Medicine, Zhongnan Hospital, Wuhan \\ University, Wuhan, People's Republic \\ of China \\ *These authors contributed equally \\ to this work
}

Background: The aim of the present study was to investigate the association between tumor necrosis factor-alpha (TNF- $\alpha$ ) gene G-238A polymorphism and risk of coronary artery disease (CAD) using a meta-analytical approach.

Methods: The PubMed and Embase databases were searched for relevant publications up to January 13, 2015. Four authors (XPH, XDZ, XTZ, and ZJZ) independently selected the studies, extracted, and analyzed the data using the Comprehensive Meta-Analysis software. The sensitivity and subgroups analyses were also performed. Either a fixed effects or a random effects model was used to estimate pooled odds ratios (ORs) and their 95\% confidence intervals (CIs).

Results: Finally, ten articles including eleven case-control studies involving 4,222 patients and 4,832 controls were yielded. The results indicated no significant association between G-238A polymorphism and CAD risk (A vs G: $\mathrm{OR}=1.08,95 \% \mathrm{CI}=0.89-1.30$; AA vs GG: $\mathrm{OR}=1.15$, $95 \% \mathrm{CI}=0.59-2.25$; GA vs $\mathrm{GG}: \mathrm{OR}=1.14,95 \% \mathrm{CI}=0.88-1.48 ; \mathrm{AA}$ vs $[\mathrm{GG}+\mathrm{GA}]: \mathrm{OR}=1.09$, $95 \% \mathrm{CI}=0.56-2.14$; (GA + AA) vs GG: OR $=1.11,95 \% \mathrm{CI}=0.90-1.38)$. In the subgroup analyses, similar results were obtained with overall populations. The sensitivity analyses showed that the overall results were robust. No publication bias was detected.

Conclusion: Based on current evidence, we can conclude that TNF- $\alpha$ G-238A polymorphism might not be associated with CAD risk.

Keywords: tumor necrosis factor-alpha, TNF- $\alpha$, polymorphism, coronary artery disease, coronary heart disease, meta-analysis

\section{Introduction}

Tumor necrosis factor-alpha $(\mathrm{TNF}-\alpha)$ is an inflammatory mediator that plays important roles in inflammatory and immune responses. ${ }^{1}$ Several single-nucleotide polymorphisms (SNPs) have been identified in the TNF- $\alpha$ promoter. ${ }^{2}$ Of these SNPs, conversion from guanine $(\mathrm{G})$ to adenine $(\mathrm{A})$ in the promoter at position-308 (rs1800629) and -238 (rs361525) has been intensively studied for these allelic variations showing functional significance. ${ }^{3,4}$ Many studies have identified that the TNF- $\alpha$ G-308A and/or G-238A are associated with many human diseases, ${ }^{5-8}$ including coronary artery disease (CAD) ${ }^{9,10}$ Of these diseases, the association between these two polymorphisms and some diseases were identified via a meta-analytical approach, from which inconsistent results can be pooled from original studies and a more precise results can be provided. ${ }^{11}$

$\mathrm{CAD}$ is also named as ischemic heart disease or coronary heart disease, mainly including stable angina pectoris, unstable angina pectoris, and myocardial infarction. ${ }^{12,13}$ Serum levels of TNF- $\alpha$ are elevated in patients with CAD and might modify the risk for developing CAD events since it affects endothelial cell hemostatic function. ${ }^{14}$ Hence,
Correspondence: Wan-Lin Wei Cadres Ward, General Hospital of Beijing Military Command, No 5 Nan Men Cang, Dongcheng, Beijing 100125, People's Republic of China

Tel +86 1084008479

Email weiwanlin2012@I26.com 
we can hypothesize that TNF- $\alpha$ gene polymorphisms might be involved in the CAD susceptibility. In 1998, Herrmann et al performed a case-control study in France and Northern Ireland population, and the results showed that the TNF- $\alpha$ gene G-308A and G-238A polymorphisms were unlikely to contribute to CAD risk in an important way. ${ }^{15}$ Since then, many epidemiological studies have been published and inconsistent results have been revealed. The association between TNF- $\alpha$ G-308A polymorphism and CAD risk has been investigated by three published meta-analyses. ${ }^{9,10,16}$ In contrast, there is no meta-analysis on the association between TNF- $\alpha$ gene G-238A polymorphism and CAD risk until now. Therefore, we conducted this meta-analysis to study the overall correlation between the G-238A polymorphism and CAD susceptibility.

\section{Materials and methods}

This meta-analysis was reported according to the Preferred Reporting Items for Systematic Reviews and Meta-Analyses (PRISMA) statement. ${ }^{17}$ As meta-analysis is a secondary analysis, ethical approval is not necessary.

\section{Eligibility criteria}

According to the PICOS ${ }^{18}$ approach, the publication was considered eligible if it met all the following criteria: 1) the patient was clearly diagnosed with CAD, coronary heart disease, ischemic heart disease, stable angina pectoris, unstable angina pectoris, myocardial infarction, or other CAD variants; 2) the exposure was the presence of G-238A polymorphism in the TNF- $\alpha$ gene; 3 ) the control group was healthy population or volunteers without coronary heart disease manifestations, either from hospital or community; 4) the outcome was the incidence of CAD, either fatal or nonfatal; and 5) the study was used a case-control design. Moreover, the information essential for calculating odds ratios (ORs) and relevant 95\% confidence intervals (CIs) should be provided. We chose the most comprehensive report if duplicate publication or overlapped information was identified.

\section{Information sources}

The PubMed and Embase databases were searched for relevant publications up to January 13, 2015. Keywords were coronary heart disease, coronary artery disease, ischemic heart disease, angina pectoris, angina, acute coronary syndrome, myocardial infarction, myocardial infarct, polymorphism, and tumor necrosis factor or TNF. References of recent reviews, previous meta-analyses, and eligibility studies were also manually scanned. Table S1 shows the search strategy used for the PubMed.

\section{Data collection}

Two authors (XPH and ZJZ) independently retrieved and selected studies for inclusion according to the aforementioned eligibility criteria. Then these two authors extracted the following data from the included studies: the last name of first author and publication year, country of origin and ethnicity, endpoints of CAD, polymorphism, sample size of cases and controls, source of controls, genotype distribution of cases and controls, genotyping method, and Hardy-Weinberg equilibrium (HWE) for control. HWE was tested by $\chi^{2}$ test at the $50 \%$ significance level. Disagreements were resolved by discussion.

\section{Data analysis}

The ORs and corresponding 95\% CIs were calculated to summarize the pooled effect sizes for G-238A polymorphism. All possible genetic models, the allelic model (A vs $G$ ), dominant model ([AG + AA] vs GG), codominant model (AA vs GG, AG vs GG), and recessive model (AA vs [AG + $\mathrm{GG}]$ ) were used to estimate the overall relationship.

First, the heterogeneity was quantitatively evaluated using the $I^{2}$ statistic. ${ }^{19}$ An $I^{2}$ value no larger than $25 \%$ indicates the absence of heterogeneity, so the fixed effects model was suggested; otherwise, the random effects model was used. The subgroup analysis was performed to investigate the source of heterogeneity and the difference between different ethnicities and HWE. The sensitivity analysis was conducted by sequential omission of individual studies to assess the influence of overall results. ${ }^{20}$ The funnel plot and Egger's test were used to detect the publication bias. ${ }^{21}$ All the analyses were conducted using the Comprehensive Meta-Analysis software (version 2.2; Biostat, Englewood, NJ, USA). ${ }^{22,23}$

\section{Results}

\section{Study selection}

The flowchart of study selection process is shown in Figure 1. A total of 253 publications were identified initially, and 175 publications were selected for further screening after removing duplicate records. After titles or abstracts were screened, a total of 59 articles preliminarily met the inclusion criteria. Four potential eligible articles were excluded because they were published in Russian and full texts could not be accessed. ${ }^{24-27}$ Two case-control studies identified in one article $^{15}$ were considered as independent studies. From four articles ${ }^{28-31}$ with overlapped population, two articles ${ }^{28,30}$ 


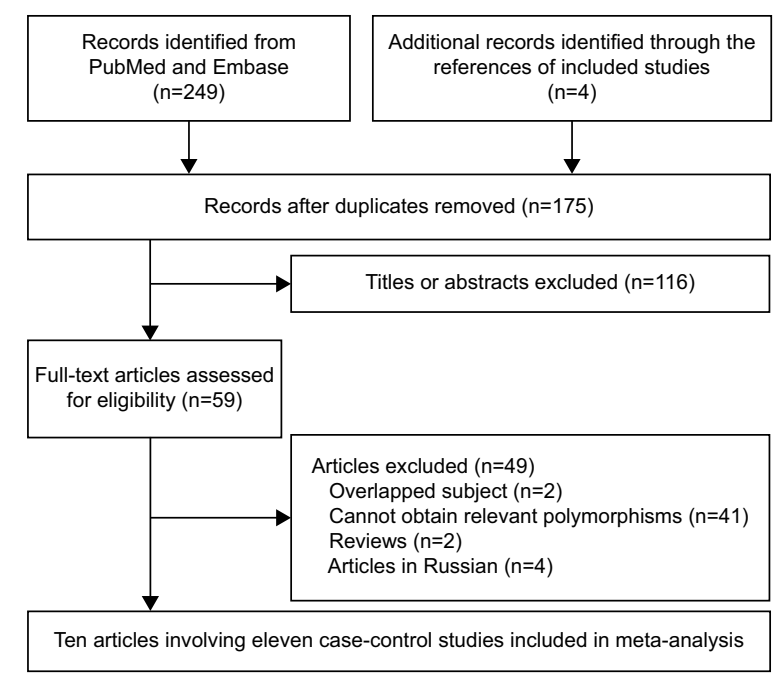

Figure I Flowchart of study section in the meta-analysis.

presenting more comprehensive information were included. Finally, ten articles with eleven case-control studies were included in this meta-analysis..$^{15,32-40}$

\section{Study characteristics}

Eleven case-control studies involving 4,222 cases and 4,832 controls investigated G-238A polymorphism. ${ }^{15,32-40}$ There were five studies based on Caucasian population ${ }^{15,32,33,35}$ and six studies concerning Asian population. ${ }^{34,36-40}$ Three of these studies were out of HWE. ${ }^{37-39}$ All controls were healthy population, eg, healthy visitors of patients, healthy volunteers, healthy blood donors, or outpatients confirmed negative by cardiac assessment. Table 1 shows the main characteristics of all the included studies.

\section{Meta-analysis}

Of the eligible eleven case-control studies, one study ${ }^{40}$ reported significant association; in contrast, the other ten studies demonstrated that the association was nonsignificant (Figure 2). The overall results of five genetic models all identified nonsignificant association between G-238A polymorphism and CAD risk (A vs G: $\mathrm{OR}=1.08,95 \%$ $\mathrm{CI}=0.89-1.30, I^{2}=34.33 \%$, Figure 2 ; AA vs GG: $\mathrm{OR}=1.15$, $95 \% \mathrm{CI}=0.59-2.25, P^{2}=0 \%$; GA vs GG: $\mathrm{OR}=1.14,95 \%$ $\mathrm{CI}=0.88-1.48, P^{2}=54.34 \%$; AA vs $[\mathrm{GG}+\mathrm{GA}]: \mathrm{OR}=1.09$, $95 \% \mathrm{CI}=0.56-2.14, I^{2}=0 \%$; $[\mathrm{GA}+\mathrm{AA}]$ vs $\mathrm{GG}: \mathrm{OR}=1.11$, $95 \% \mathrm{CI}=0.90-1.38, I^{2}=41.92 \%$ ).

After being stratified by ethnicity, the results of Asian and Caucasian populations were similar to that of the overall population. The studies in HWE also revealed nonsignificant association. Table 2 shows the overall and subgroup analyses results of G-238A polymorphism and CAD risk. The sensitivity analysis showed that none of the included eleven studies dramatically influenced the pooled results under all the five genetic models (Figure 3).

\section{Publication bias}

The funnel plots (Figure 4) and Egger's test demonstrated that there was no publication bias in our meta-analysis ( $P=0.28$ for

Table I Characteristics of the included studies

\begin{tabular}{|c|c|c|c|c|c|c|c|c|c|}
\hline \multirow[t]{2}{*}{ Study } & \multirow[t]{2}{*}{$\begin{array}{l}\text { Country } \\
\text { (ethnicity) }\end{array}$} & \multirow[t]{2}{*}{ Disease } & \multirow[t]{2}{*}{$\begin{array}{l}\text { Sample } \\
\text { (Ca/Co) }\end{array}$} & \multicolumn{3}{|c|}{$\begin{array}{l}\text { Genotype frequency } \\
(\mathrm{Ca} / \mathrm{Co})\end{array}$} & \multirow[t]{2}{*}{$\begin{array}{l}\text { Source of } \\
\text { controls }\end{array}$} & \multirow[t]{2}{*}{$\begin{array}{l}\text { Genotype } \\
\text { method }\end{array}$} & \multirow[t]{2}{*}{$\begin{array}{l}\text { HWE for } \\
\text { controls }\end{array}$} \\
\hline & & & & GG & GA & AA & & & \\
\hline Herrmann I (1998) & $\begin{array}{l}\text { Northern Ireland } \\
\text { (Caucasian) }\end{array}$ & MI & $196 / 176$ & $168 / 161$ & $27 / 15$ & $\mathrm{I} / 0$ & Healthy & PCR-SSCP & Yes \\
\hline Herrmann F (1998) ${ }^{15}$ & France (Caucasian) & MI & $446 / 531$ & $408 / 48 I$ & $36 / 48$ & $2 / 2$ & Healthy & PCR-SSCP & Yes \\
\hline Allen et al ${ }^{12}$ & UK (Caucasian) & CAD & $180 / 250$ & $162 / 220$ & $17 / 29$ & $\mathrm{I} / \mathrm{I}$ & Healthy & PCR-RFLP & Yes \\
\hline Szalai et a $\mathrm{a}^{33}$ & Hungary (Caucasian) & CAD & $318 / 248$ & $287 / 225$ & $31 / 23$ & $0 / 0$ & Healthy & PCR-RFLP & Yes \\
\hline Xiang et al ${ }^{34}$ & $\begin{array}{l}\text { People's Republic of } \\
\text { China (Asian) }\end{array}$ & $\mathrm{CHD}$ & $162 / 182$ & $154 / 176$ & $7 / 6$ & $\mathrm{I} / 0$ & Healthy & PCR-RFLP & Yes \\
\hline Bennet et $\mathrm{a}^{35}$ & Sweden (Caucasian) & MI & $\mathrm{I}, 150 / \mathrm{I}, 468$ & $\mathrm{I}, 068 / \mathrm{I}, 348$ & $75 / 119$ & $7 / 1$ & Healthy & PCR-RFLP & Yes \\
\hline Hou et $\mathrm{al}^{36}$ & $\begin{array}{l}\text { People's Republic of } \\
\text { China (Asian) }\end{array}$ & $\mathrm{CHD}$ & $804 / 905$ & $740 / 819$ & $63 / 86$ & $\mathrm{I} / 0$ & Healthy & PCR-RFLP & Yes \\
\hline Liu et $\mathrm{a}^{37}$ & $\begin{array}{l}\text { People's Republic of } \\
\text { China (Asian) }\end{array}$ & $\mathrm{CHD}$ & $276 / 202$ & $248 / 191$ & $24 / 7$ & $4 / 4$ & Healthy & PCR-RFLP & No \\
\hline Sun et $\mathrm{al}^{38}$ & $\begin{array}{l}\text { People's Republic of } \\
\text { China (Asian) }\end{array}$ & $\mathrm{CHD}$ & $73 / 138$ & $70 / 129$ & $3 / 8$ & $0 / 1$ & Healthy & PCR-RFLP & No \\
\hline Liu et $\mathrm{a}^{39}$ & $\begin{array}{l}\text { People's Republic of } \\
\text { China (Asian) }\end{array}$ & CAD & $420 / 328$ & $388 / 311$ & $28 / 11$ & $4 / 6$ & Healthy & PCR-RFLP & No \\
\hline Cho et $\mathrm{al}^{40}$ & South Korea (Asian) & CAD & $197 / 404$ & $|69 / 37|$ & $28 / 32$ & $0 / 1$ & Healthy & PCR-RFLP & Yes \\
\hline
\end{tabular}

Notes: Herrmann I 1998, the study conducted in Northern Ireland; Herrmann F 1998, the study conducted in France.

Abbreviations: Ca, case group; Co, control group; CAD, coronary artery disease; CHD, coronary heart disease; MI, myocardial infarction; HWE, Hardy-Weinberg equilibrium; PCR-SSCP, polymerase chain reaction single-strand conformation polymorphism; PCR-RFLP, polymerase chain reaction-restriction fragment length polymorphism. 


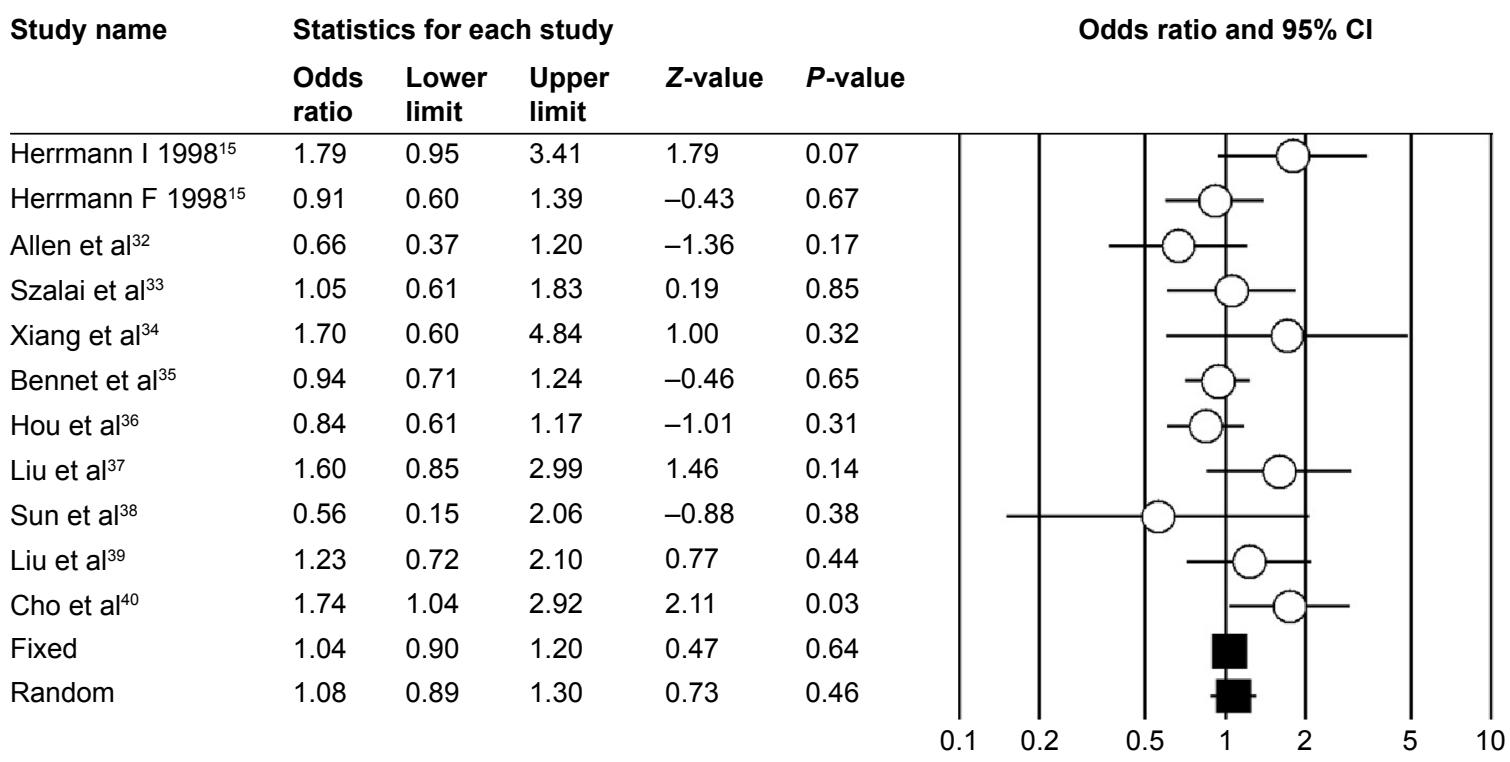

Figure 2 Forest plot of overall population of TNF- $\alpha$ G-238A polymorphism and CAD risk (A vs G model). Notes: Herrmann I 1998, the study conducted in Northern Ireland; Herrmann F 1998, the study conducted in France. Abbreviations: TNF- $\alpha$, tumor necrosis factor-alpha; CAD, coronary artery disease; $\mathrm{Cl}$, confidence interval.

A vs $\mathrm{G} ; P=0.14$ for $\mathrm{AA}$ vs $\mathrm{GG} ; P=0.06$ for $\mathrm{GA}$ vs $\mathrm{GG} ; P=0.17$ for $\mathrm{AA}$ vs $[\mathrm{GG}+\mathrm{GA}] ; P=0.12[\mathrm{GA}+\mathrm{AA}]$ vs $\mathrm{GG})$.

\section{Discussion}

CAD remains the major cause of mortality and morbidity worldwide. Smoking, diabetes, hypertension, obesity,

Table 2 Results of overall estimates and subgroup analysis

\begin{tabular}{|c|c|c|c|c|}
\hline \multirow{2}{*}{$\begin{array}{l}\text { Genetic } \\
\text { model }\end{array}$} & \multicolumn{4}{|c|}{ G-238A polymorphism } \\
\hline & Studies & OR $(95 \% \mathrm{Cl})$ & Model & $I^{2}(\%)$ \\
\hline \multicolumn{5}{|l|}{$A$ vs $G$} \\
\hline Overall & 11 & $1.08(0.89-1.30)$ & REM & 34.33 \\
\hline Asian & 6 & $1.21(0.88-1.68)$ & REM & 42.46 \\
\hline Caucasian & 5 & $0.98(0.77-1.24)$ & REM & 25.48 \\
\hline HWE (yes) & 8 & $1.04(0.84-1.30)$ & REM & 41.47 \\
\hline \multicolumn{5}{|l|}{ AA vs GG } \\
\hline Overall & 11 & $1.15(0.59-2.25)$ & FEM & 0 \\
\hline Asian & 6 & $0.79(0.35-1.78)$ & FEM & 0 \\
\hline Caucasian & 5 & $2.60(0.79-8.48)$ & FEM & 0 \\
\hline HWE (yes) & 8 & $2.42(0.89-6.55)$ & FEM & 0 \\
\hline \multicolumn{5}{|l|}{ AG vs GG } \\
\hline Overall & 11 & $1.14(0.88-1.48)$ & REM & 54.34 \\
\hline Asian & 6 & $1.43(0.88-2.33)$ & REM & 64.4 \\
\hline Caucasian & 5 & $0.91(0.74-1.11)$ & FEM & 15.9 \\
\hline HWE (yes) & 8 & $1.02(0.80-1.30)$ & REM & 44.86 \\
\hline \multicolumn{5}{|c|}{$A A$ vs $(A G+G G)$} \\
\hline Overall & II & $1.09(0.56-2.14)$ & FEM & 0 \\
\hline Asian & 6 & $0.76(0.34-1.7 I)$ & FEM & 0 \\
\hline Caucasian & 5 & $2.38(0.73-7.77)$ & FEM & 0 \\
\hline HWE (yes) & 8 & $2.26(0.83-6.12)$ & FEM & 0 \\
\hline \multicolumn{5}{|c|}{$(A G+A A)$ vs $G G$} \\
\hline Overall & II & $1.11(0.90-1.38)$ & REM & 41.92 \\
\hline Asian & 6 & $1.31(0.88-1.94)$ & REM & 53.62 \\
\hline Caucasian & 5 & $0.96(0.77-1.18)$ & FEM & 8.18 \\
\hline HWE (yes) & 8 & $1.05(0.83-1.30)$ & REM & 39.85 \\
\hline
\end{tabular}

Abbreviations: $\mathrm{OR}$, odds ratio; $\mathrm{Cl}$, confidence interval; $\mathrm{REM}$, random effect model; HWE, Hardy-Weinberg equilibrium; FEM, fixed effect model. family history, stress, hyperlipidemia, and alcohol abuse were considered the conventional risk factors of CAD; however, these conventional factors can only explain $50 \%$ of the total risk factors of CAD cases. ${ }^{41-47}$ Genetic factors might contribute to the other half of the total risk factors, and many polymorphisms are considered to be associated with the onset and development of CAD. ${ }^{12,46,48-51}$ Our metaanalysis focused on the TNF- $\alpha$ gene promoter G-238A polymorphism and revealed that this polymorphism was not associated with CAD risk. In the subgroup analyses, similar results with overall population were obtained, and the sensitivity analyses showed that the overall results were robust.

There were ten publications with eleven case-control studies focusing on the G-238A polymorphism and CAD risk in our meta-analysis. According to the result of literature search, our meta-analysis is the first metaanalysis on the G-238A polymorphism. Similar to G-308A polymorphism, ${ }^{9,10,16}$ our result also revealed a nonsignificant association between G-238A polymorphism and risk of CAD. We also performed subgroup analysis to investigate the effects of ethnicity and HWE. Only Asian and Caucasian populations were adopted. The subgroup analysis revealed no association for Asian population, Caucasian population, and the studies in HWE. Considering the interesting phenomenon of G-308A polymorphism, ${ }^{9,10,16}$ the G-238A polymorphism included small number of studies and needs further research. In other words, the current result is not the final result. 


\begin{tabular}{|c|c|c|c|c|c|c|}
\hline \multirow[t]{2}{*}{ Study name } & \multicolumn{5}{|c|}{ Statistics with study removed } & \multirow{2}{*}{$\begin{array}{l}\text { Odds ratio }(95 \% \mathrm{Cl}) \\
\text { with study removed }\end{array}$} \\
\hline & Point & $\begin{array}{l}\text { Lower } \\
\text { limit }\end{array}$ & $\begin{array}{l}\text { Upper } \\
\text { limit }\end{array}$ & Z-value & $P$-value & \\
\hline Herrmann I $1998^{15}$ & 1.03 & 0.85 & 1.24 & 0.30 & 0.77 & \\
\hline Herrmann F $1998^{15}$ & 1.11 & 0.89 & 1.38 & 0.91 & 0.36 & \\
\hline Allen et $a^{32}$ & 1.11 & 0.92 & 1.35 & 1.09 & 0.27 & \\
\hline Szalai et $\mathrm{al}^{33}$ & 1.08 & 0.87 & 1.34 & 0.74 & 0.46 & \\
\hline Xiang et $\mathrm{al}^{34}$ & 1.06 & 0.87 & 1.29 & 0.58 & 0.56 & \\
\hline Bennet et al ${ }^{35}$ & 1.12 & 0.89 & 1.40 & 0.93 & 0.35 & \\
\hline Hou et $\mathrm{al}^{36}$ & 1.13 & 0.91 & 1.39 & 1.09 & 0.28 & \\
\hline Liu et $a^{37}$ & 1.04 & 0.86 & 1.27 & 0.40 & 0.69 & \\
\hline Sun et $\mathrm{al}^{38}$ & 1.09 & 0.90 & 1.33 & 0.87 & 0.39 & \\
\hline Liu et al ${ }^{39}$ & 1.07 & 0.86 & 1.32 & 0.59 & 0.56 & \\
\hline \multirow[t]{2}{*}{ Cho et $\mathrm{al}^{40}$} & 1.01 & 0.84 & 1.20 & 0.09 & 0.93 & \\
\hline & 1.08 & 0.89 & 1.30 & 0.73 & 0.46 & \\
\hline
\end{tabular}

Figure 3 Forest plot of sensitivity analysis by omitting a single study each time of overall population of TNF- $\alpha$ G-238A polymorphism and CAD risk (A vs G model). Notes: Herrmann I 1998, the study conducted in Northern Ireland; Herrmann F 1998, the study conducted in France.

Abbreviations: TNF- $\alpha$, tumor necrosis factor-alpha; CAD, coronary artery disease; $\mathrm{Cl}$, confidence interval.

For this polymorphism, how many new studies should be conducted in the future remains a question. Based on current evidence, we could not judge whether the sample size was sufficient for decisive conclusion. Moreover, whether significant correlation between G-238A polymorphism and risk of CAS exists in other ethnicity, such as Africans or Turks, remains unclear. Also, the polymorphism associated with patients with CAD and concomitant diseases, such as periodontal disease, ${ }^{52}$ also needs to be examined in further researches. Moreover, our meta-analysis also provides some clinical implications. We knew that, the personalized drug treatment is involved in the genetic background. Hence, development of a special drug for patients with CAD with G-238A polymorphism is not needed. However, the clinicians should advise their patients with this polymorphism to have peace of mind and not to take this polymorphism as a risk factor in the clinical work.
TNF- $\alpha$ G-238A polymorphism might not be considered for the genetic diagnosis of CAD.

Obviously, heterogeneity was large in three genetic models. Mild heterogeneity detected in certain genetic models and subgroup analyses was only partially explained by ethnicity and HWE (Table 2). The heterogeneity is common in meta-analysis of genetic association studies, ${ }^{23,53-55}$ and we should not ignore it since pooled results may be influenced by heterogeneity. Therefore, the substantial heterogeneity was one limitation of our meta-analysis. Second, as all the included studies were limited within Asians or Caucasians, our conclusion may not be reasonably extrapolated for other ethnic groups. Third, the sample size from eligible studies was not enough. The small sample size might influence the result. Although we tried our best to collect all the relevant studies, certain publications published in languages other

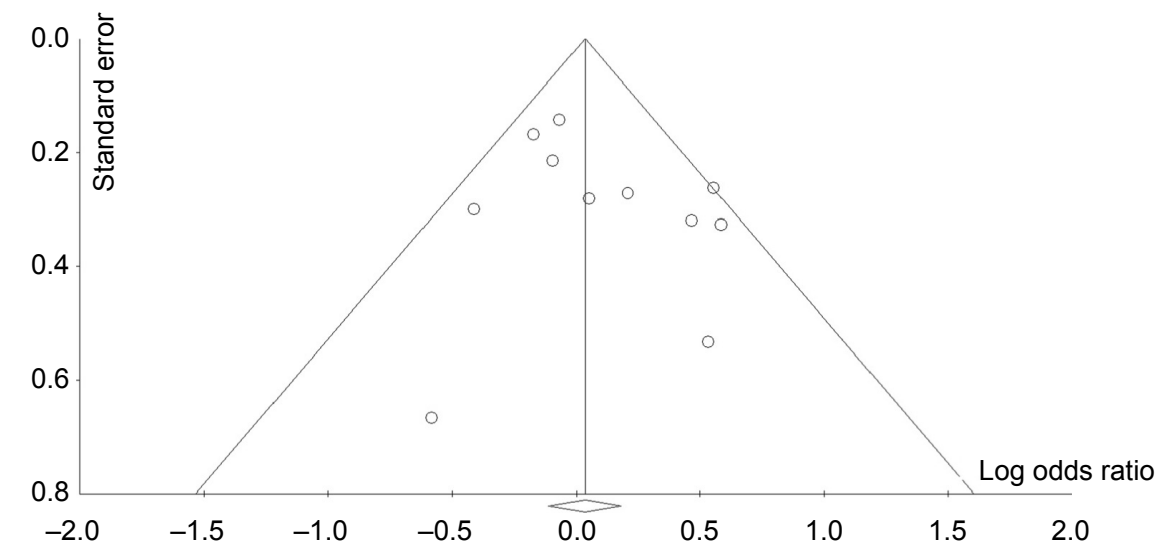

Figure 4 Funnel plot of standard error by log odds ratio for detection publication bias of G-238A polymorphism (A vs G model). 
than English or Chinese were excluded because of inaccessibility to the full text and/or impenetrability due to language barriers. Hence, although the test for publication bias revealed no publication bias in our meta-analysis, the bias that originated from publication bias should not be ignored. Fourth, for lacking original data of gene-gene and geneenvironmental interactions and adjusted conventional risk factors, we could not further evaluate potential gene-gene and gene-environmental interactions based on adjusted ORs. Finally, for lacking appropriate methodological quality tool, ${ }^{11}$ we did not assess the risk of bias of included studies. Hence, current results based on unadjusted data may be confounded to the pooled effect.

\section{Conclusion}

In conclusion, there was no evidence suggesting that TNF- $\alpha$ G-238A polymorphism was associated with the risk of CAD. The nonsignificant results were without ethnic difference. Due to the limitations and implications of current meta-analysis, we suggest that further well-designed studies with large sample size should be conducted to clarify the association between the polymorphisms and CAD risk, among which meta-analysis of genome-wide association studies ${ }^{56}$ is the best.

\section{Acknowledgments}

This study was supported by the National Natural Science Foundation of the People's Republic of China (No 81273971). The funders had no roles in study design, data collection and analysis, decision to publish, or preparation of the manuscript.

\section{Disclosure}

The authors report no conflicts of interest in this work.

\section{References}

1. Gowers IR, Walters K, Kiss-Toth E, Read RC, Duff GW, Wilson AG. Age-related loss of $\mathrm{CpG}$ methylation in the tumour necrosis factor promoter. Cytokine. 2011;56(3):792-797.

2. Allen RD. Polymorphism of the human TNF-alpha promoter - random variation or functional diversity? Mol Immunol. 1999;36(15-16): 1017-1027.

3. Falvo JV, Tsytsykova AV, Goldfeld AE. Transcriptional control of the TNF gene. Curr Dir Autoimmun. 2010;11:27-60.

4. D'Alfonso S, Richiardi PM. A polymorphic variation in a putative regulation box of the TNFA promoter region. Immunogenetics. 1994;39(2): $150-154$.

5. Song GG, Choi SJ, Ji JD, Lee YH. Association between tumor necrosis factor-alpha promoter-308 A/G, $-238 \mathrm{~A} / \mathrm{G}$, interleukin-6-174 G/C and $-572 \mathrm{G} / \mathrm{C}$ polymorphisms and periodontal disease: a meta-analysis. Mol Biol Rep. 2013;40(8):5191-5203.

6. Cheng K, Zhao YJ, Liu L, Wan JJ. Tumor necrosis factor-alpha $238 \mathrm{G} / \mathrm{A}$ polymorphism and risk of hepatocellular carcinoma: evidence from a meta-analysis. Asian Pac J Cancer Prev. 2013;14(5):3275-3279.
7. Zhuang L, Ma W, Cai D, Zhong H, Sun Q. Associations between tumor necrosis factor-alpha polymorphisms and risk of psoriasis: a meta-analysis. PLoS One. 2013;8(12):e68827.

8. Li YY. Tumor necrosis factor-alpha g308alpha gene polymorphism and essential hypertension: a meta-analysis involving 2244 participants. PLoS One. 2012;7(4):e35408.

9. Zhang HF, Xie SL, Wang JF, Chen YX, Wang Y, Huang TC. Tumor necrosis factor-alpha G-308A gene polymorphism and coronary heart disease susceptibility: an updated meta-analysis. Thromb Res. 2011; 127(5):400-405.

10. Pereira TV, Rudnicki M, Franco RF, Pereira AC, Krieger JE. Effect of the G-308A polymorphism of the tumor necrosis factor alpha gene on the risk of ischemic heart disease and ischemic stroke: a meta-analysis. Am Heart J. 2007;153(5):821-830.

11. Zeng X, Zhang Y, Kwong JS, et al. The methodological quality assessment tools for preclinical and clinical studies, systematic review and meta-analysis, and clinical practice guideline: a systematic review. J Evid Based Med. 2015;8(1):2-10.

12. Lieb W, Vasan RS. Genetics of coronary artery disease. Circulation. 2013;128(10):1131-1138.

13. Glozier N, Tofler GH, Colquhoun DM, et al. Psychosocial risk factors for coronary heart disease. Med J Aust. 2013;199(3):179-180.

14. Plutzky J. Inflammatory pathways in atherosclerosis and acute coronary syndromes. Am J Cardiol. 2001;88(8):10-15.

15. Herrmann SM, Ricard S, Nicaud V, et al. Polymorphisms of the tumour necrosis factor-alpha gene, coronary heart disease and obesity. Eur J Clin Invest. 1998;28(1):59-66.

16. Chu H, Yang J, Mi S, et al. Tumor necrosis factor-alpha G-308 A polymorphism and risk of coronary heart disease and myocardial infarction: a case-control study and meta-analysis. J Cardiovasc Dis Res. 2012;3(2):84-90.

17. Moher D, Liberati A, Tetzlaff J, Altman DG, Group P. Preferred reporting items for systematic reviews and meta-analyses: the PRISMA statement. PLoS Med. 2009;6(7):e1000097.

18. Liberati A, Altman DG, Tetzlaff J, et al. The PRISMA statement for reporting systematic reviews and meta-analyses of studies that evaluate health care interventions: explanation and elaboration. BMJ. 2009;6(7).

19. Higgins JP, Thompson SG, Deeks JJ, Altman DG. Measuring inconsistency in meta-analyses. BMJ. 2003;327(7414):557-560.

20. Patsopoulos NA, Evangelou E, Ioannidis JP. Sensitivity of betweenstudy heterogeneity in meta-analysis: proposed metrics and empirical evaluation. Int J Epidemiol. 2008;37(5):1148-1157.

21. Egger M, Davey Smith G, Schneider M, Minder C. Bias in meta-analysis detected by a simple, graphical test. BMJ. 1997;315(7109):629-634.

22. Borenstein M, Hedges L, Higgins J, et al. Comprehensive Meta-Analysis: A Computer Program for Meta-Analysis [Computer Program]. Englewood, NJ: Biostat Inc; 2007.

23. Yan Y, Weng H, Shen ZH, Wu L, Zeng XT. Association between interleukin-4 gene - $590 \mathrm{c} / \mathrm{t},-33 \mathrm{c} / \mathrm{t}$, and 70-base-pair polymorphisms and periodontitis susceptibility: a meta-analysis. J Periodontol. 2014;85(11):e354-e362.

24. Sukhinina TS, Shakhnovich RM, Barsova RM, et al. [Value of allele gene polymorphism of the inflammation system for prognosis of patients with myocardial infarction]. Kardiologiia. 2012;52(3):15-21. Russian [with English abstract].

25. Konenkov VI, Shevchenko AV, Prokof'ev VF, Maksimov VN. [Complex of genotypes of cytokines as a genetic factor of risk of development of myocardial infarction of in European population of Russia men]. Kardiologiia. 2012;52(7):22-29. Russian [with English abstract].

26. Shevchenko AV, Golovanova OV, Konenkov VI, et al. [Analysis of polymorphism of three positions of promoter region of TNF-gene in patients with ischemic heart disease, unstable angina and myocardial infarction]. Kardiologiia. 2010;50(2):9-14. Russian [with English abstract].

27. Sudomoina MA, Sukhinina TS, Barsova RM, et al. [Complex analysis of association of inflammation genes with myocardial infarction]. Mol Biol (Mosk). 2010;44(3):463-471. Russian [with English abstract]. 
28. Szabo GV. The role and importance of gene polymorphisms in the development of atherosclerosis. Interv Med Appl Sci. 2013;5(1):46-51.

29. Szabo GV, Acsady G. Tumornecrosis-factor-alpha 308 GA polymorphism in atherosclerotic patients. Pathol Oncol Res. 2011;17(4):853-857.

30. Ghazouani L, Khalifa SB, Abboud N, et al. $-308 \mathrm{G}>\mathrm{A}$ and $-1031 \mathrm{~T}>\mathrm{C}$ tumor necrosis factor gene polymorphisms in Tunisian patients with coronary artery disease. Clin Chem Lab Med. 2009;47(10):1247-1251.

31. Ghazouani L, Ben Hadj Khalifa S, Abboud N, et al. TNF-alpha -308G $>$ A and IL-6 -174G $>$ C polymorphisms in Tunisian patients with coronary artery disease. Clin Biochem. 2010;43(13-14):1085-1089.

32. Allen RA, Lee EM, Roberts DH, Park BK, Pirmohamed M. Polymorphisms in the TNF-alpha and TNF-receptor genes in patients with coronary artery disease. Eur J Clin Invest. 2001;31(10):843-851.

33. Szalai C, Fust G, Duba J, et al. Association of polymorphisms and allelic combinations in the tumour necrosis factor-alpha-complement $\mathrm{MHC}$ region with coronary artery disease. J Med Genet. 2002;39(1):46-51.

34. Xiang PX, Li Y, Zhang PA, Huang CX. Study on plasma TNFa level and TNFa polymorphisms in patients with coronary heart disease. Jian Yan Yi Xue. 2004;19(5):434-437. Chinese [with English abstract].

35. Bennet AM, van Maarle MC, Hallqvist J, et al. Association of TNFalpha serum levels and TNFA promoter polymorphisms with risk of myocardial infarction. Atherosclerosis. 2006;187(2):408-414.

36. Hou L, Huang J, Lu X, Wang L, Fan Z, Gu D. Polymorphisms of tumor necrosis factor alpha gene and coronary heart disease in a Chinese Han population: interaction with cigarette smoking. Thromb Res. 2009; 123(6):822-826.

37. Liu Y, Jin W, Lu L, Chen QJ, Shen WF. Association between single nucleotide polymorphism in tumor necrosis factor- $\alpha$ gene promoter and coronary heart disease. Zhen Duan Xue Li Lun Yu Shi Jian. 2009; 8(5):506-509. Chinese [with English abstract].

38. Sun SY, Zeng XQ, Jin AM, Fan WH, Zhang JC. Association of tumor necrosis factor alpha gene polymorphisms in the promoter region with chronic periodontitis and coronary heart disease. Lin Chuang Kou Qiang Yi Xue Za Zhi. 2009;5(5):279-282. Chinese [with English abstract].

39. Liu Y, Lu L, Wu ZJ, Chen QJ, Shen WF, Jin W. Relationship between tumor necrosis factor-a gene and risk of coronary artery disease in Shanghai Han population. Shaghai Jiao Tong Da Xue Xue Bao (Yi Xue Ban). 2011;31(5):592-597. Chinese [with English abstract].

40. Cho HC, Yu G, Lee MY, Kim HS, Shin DH, Kim YN. TNF-alpha polymorphisms and coronary artery disease: association study in the Korean population. Cytokine. 2013;62(1):104-109.

41. Muhlestein JB. Secondary prevention of coronary artery disease with antimicrobials: current status and future directions. Am J Cardiovasc Drugs. 2002;2(2):107-118.
42. Gibson CM, Cannon CP, Greene RM, et al. Rescue angioplasty in the thrombolysis in myocardial infarction (TIMI) 4 trial. Am J Cardiol. 1997; 80(1):21-26.

43. Yusuf S, Hawken S, Ounpuu S, et al; INTERHEART Study Investigators. Effect of potentially modifiable risk factors associated with myocardial infarction in 52 countries (the INTERHEART study): case-control study. Lancet. 2004;364(9438):937-952.

44. Nilsson PM, Nilsson JA, Berglund G. Population-attributable risk of coronary heart disease risk factors during long-term follow-up: the Malmo preventive project. J Intern Med. 2006;260(2):134-141.

45. Edmondson D, Newman JD, Whang W, Davidson KW. Emotional triggers in myocardial infarction: do they matter? Eur Heart J. 2013; 34(4):300-306.

46. Simon AS, Vijayakumar T. Molecular studies on coronary artery disease-a review. Indian J Clin Biochem. 2013;28(3):215-226.

47. Ohira T, Iso H. Cardiovascular disease epidemiology in Asia: an overview. Circ J. 2013;77(7):1646-1652.

48. Xu Q, Yuan F, Shen X, et al. Polymorphisms of C242T and A640G in CYBA gene and the risk of coronary artery disease: a meta-analysis. PLoS One. 2014;9(1):e84251.

49. Lin B, Huang Y, Zhang M, Wang J, Wu Y. Association between apolipoprotein C3 Sst I, T-455C, C-482T and C1100T polymorphisms and risk of coronary heart disease. BMJ Open. 2014;4(1):e004156.

50. Wu Z, Lou Y, Lu L, et al. Heterogeneous effect of two selectin gene polymorphisms on coronary artery disease risk: a meta-analysis. PLoS One. 2014;9(2):e88152.

51. Wang X, Zhang J, Du X, Song M, Jia C, Liu H. Association of A561C and G98T polymorphisms in E-selectin gene with coronary artery disease: a meta-analysis. PLoS One. 2013;8(11):e79301.

52. Leng WD, Zeng XT, Kwong JS, Hua XP. Periodontal disease and risk of coronary heart disease: An updated meta-analysis of prospective cohort studies. Int J Cardiol. 201:469-472.

53. Zeng XT, Liu DY, Kwong JS, Leng WD, Xia LY, Mao M. Meta-analysis of association between interleukin-1beta C-511T polymorphism and chronic periodontitis susceptibility. J Periodontol. 2015;86(6): $812-819$.

54. Zhang L, Chen LM, Wang MN, et al. The G894t, T-786c and 4b/a polymorphisms in Enos gene and cancer risk: a meta-analysis. J Evid Based Med. 2014;7(4):263-269.

55. Zeng XT, Luo W, Geng PL, Guo Y, Niu YM, Leng WD. Association between the TP53 codon 72 polymorphism and risk of oral squamous cell carcinoma in Asians: a meta-analysis. BMC Cancer. 2014;14: 469.

56. Hou L, Zhao H. A review of post-GWAS prioritization approaches. Front Genet. 2013;4:280. 


\section{Supplementary material}

Table SI The search strategy of PubMed

\begin{tabular}{|c|c|c|}
\hline No & Query results & Results \\
\hline \multirow[t]{4}{*}{14} & Search $((((((($ coronary heart disease[Text Word]) OR ischemic heart disease[Text Word]) OR angina pectori[Text & 159 \\
\hline & Word]) OR angina[Text Word]) OR acute coronary syndrome[Text Word]) OR myocardial infarction[Text Word]) & \\
\hline & OR myocardial infarct[Text Word]) OR coronary artery disease[MeSH]) AND ((tumor necrosis factor[Text Word]) & \\
\hline & OR TNF[Text Word]) AND polymorphism[Text Word] & \\
\hline 13 & Search polymorphism[Text Word] & 229,416 \\
\hline 12 & Search (tumor necrosis factor[Text Word]) OR TNF[Text Word] & 167,359 \\
\hline II & Search TNF[Text Word] & II3,07| \\
\hline 10 & Search tumor necrosis factor[Text Word] & 136,792 \\
\hline \multirow[t]{3}{*}{9} & Search $(((((($ coronary heart disease[Text Word $])$ OR ischemic heart disease[Text Word] $)$ OR angina pectori[Text & 304,794 \\
\hline & Word]) OR angina[Text Word]) OR acute coronary syndrome[Text Word]) OR myocardial infarction[Text Word]) & \\
\hline & OR myocardial infarct[Text Word]) OR coronary artery disease[MeSH] & \\
\hline 8 & Search Coronary Artery Disease[MeSH] & 37,314 \\
\hline 7 & Search myocardial infarct[Text Word] & 18,735 \\
\hline 6 & Search myocardial infarction[Text Word] & 189,875 \\
\hline 5 & Search acute coronary syndrome[Text Word] & 14,457 \\
\hline 4 & Search angina[Text Word] & 60,634 \\
\hline 3 & Search angina pectori[Text Word] & 0 \\
\hline 2 & Search ischemic heart disease[Text Word] & 20,146 \\
\hline I & Search coronary heart disease[Text Word] & 39,801 \\
\hline
\end{tabular}

\section{Publish your work in this journal}

Therapeutics and Clinical Risk Management is an international, peerreviewed journal of clinical therapeutics and risk management, focusing on concise rapid reporting of clinical studies in all therapeutic areas, outcomes, safety, and programs for the effective, safe, and sustained use of medicines. This journal is indexed on PubMed Central, CAS,
EMBase, Scopus and the Elsevier Bibliographic databases. The manuscript management system is completely online and includes a very quick and fair peer-review system, which is all easy to use. Visit http://www.dovepress.com/testimonials.php to read real quotes from published authors. 